\title{
Working posture analysis on oyster mushroom farmers using OWAS method in Lempake, Samarinda, East Kalimantan
}

\author{
Lina D. Fathimahhayati $1^{1^{*}}$, Theresia A. Pawitra ${ }^{1 *}$, Willy Tambunan ${ }^{1}$, Markus Hartono ${ }^{2}$ \\ ${ }^{1}$ Department of Industrial Engineering, Faculty of Engineering, Mulawarman University, Samarinda, \\ Indonesia \\ ${ }^{2}$ Department of Industrial Engineering, Faculty of Engineering, University of Surabaya, Surabaya, \\ Indonesia
}

\section{ARTICLE INFO}

\section{Article History}

Received:

July 4, 2021

Accepted: $\quad$ Augustus 3, 2021

Published: Augustus 29, 2021

\section{Keywords:}

oyster mushroom cultivation, working posture,

OWAS

\section{Cite this:}

J. IIm. Pertan., 2021, 18 (1) 1-11

DOI:

https://doi.org/10.31849/jip.v18i1.7197

\section{ABSTRACT}

A preliminary survey showed that oyster mushroom farmers in Lempake Samarinda experienced pain in several body segments, especially at their waist. It may be attributable to the working condition that requires nonergonomic postures such as frequent awkward posture in sitting or standing position. Therefore, this paper aims to assess the working posture in oyster mushroom farmers. Ovako Working Posture Analysis System (OWAS) method was applied to measure the risk level of farmers' working posture. A total of ten activities were observed from the oyster mushroom cultivations' process in four cultivations in Lempake, Samarinda, Indonesia. Each activity was assessed using the OWAS category based on the position of the back, arms, legs, and load. The result showed that $10 \%$ of farmers' working posture was classified in the $4^{\text {th }}$ risk level category, categorized as highly dangerous for the musculoskeletal system, so direct improvement was needed. Furthermore, $10 \%$ of working postures were classified in the $3^{\text {rd }}$ risk level category, and $60 \%$ of working posture was in the $2^{\text {nd }}$ risk level category, which is categorized as dangerous for the musculoskeletal system and could cause significant tension so that improvement in the future as needed. On the other hand, $20 \%$ of working posture was classified in the $1^{\text {st }}$ category which was safe for the musculoskeletal system.

\section{INTRODUCTION}

According to International Labour Organization (ILO), musculoskeletal disorder (MSD) is an acute, chronic disorder that can harm the function of different body parts (Gomez-Gallan et al., 2017). This musculoskeletal disorder is triggered by the work itself, depending on the workplace and worker. Grandjean (1993) confirmed that frequent static loads on the muscle could damage the joints, ligaments, and tendons in excessive hours. Thus, the worker feels light or intense pain in his skeletal muscle ranging. Further, MSD that is related to work is termed WMSD (Work-related musculoskeletal disorders). According to the Canadian Centre of Occupational Health and Safety, WMSDs are a group of painful disorders of muscles, tendons, and nerves, for example, carpal tunnel syndrome, tendonitis, thoracic outlet syndrome, and tension neck syndrome. Awkward and static postures cause the development of WMSD symptoms, continuous repetition of movement, force fixed on a small part of the body, such as the wrist. WMSD leads to a short or long-term absence, functional limitation, work disabilities, and reduced workers' quality of life (Dianat et al., 2020). Furthermore, the economic impact of WMSD is enormous, and it is predicted to escalate in the future (Niu, 2010). Therefore, WMSD has a severe impact on the workers, communities, and the government.

Agriculture is one of the most dangerous occupations in the world, according to the ILO (2000). Ergonomics factors such as using inadequate equipment and tools, awkward static posture in sitting and standing, carrying of heavy loads, repetitive handwork, and excessively long hours working are the frequent hazard occurs in agriculture (ILO, 2000, Kirk-horn et al., 2010 in Dianat et al., 2020). Previous studies acknowledged that WMSD is the most common

${ }^{*}$ Corresponding Author

E-mail: linadianatif@ft.unmul.ac.id 
non-fatal injury and illness among farmers (McCurdy et al., 2003; Fathallah, 2010). Choi et al. (2020) also stated that the incidence of MSD in the main body, hands/wrist, and shoulders was very high on Asian farmers. Furthermore, Kumaraveloo and Lunner Kolstrup (2018) in Dianat et al.(2020) reported that besides physical factors, individual and psychosocial risk might contribute to the development of MSD in agricultural workers. However, Dianat et al. (2020) argued that the contribution of psychosocial risk (e.g., work pressure, job satisfaction, and income) on MSD symptoms is unclear since few studies only reported the contribution of job factors (i.e., job tenure and workload). Therefore, MSD risks need to be eliminated or reduced.

Many studies have been examined the risk factors of WMSD in agriculture workers (Dianat et al., 2020). These studies investigated MSD risk in farmers from several countries such as Netherland (Hildebrand, 1995), South Africa (Naidoo et al., 2009), Irish (Osborne et al., 2010), United States (Lee et al., 2014), and Korea (Kang et al., 2016). However, fewer studies researched identifying MSD risk of a specific group of farmers such as greenhouse workers (Lopez-Aragon et al., 2018), rice farmers (Das, 2015), vegetable growers (Min et al., 2016), seaweed farmers (Pratiwi, 2020), and rubber farmers (Ardiansyah, 2018).

One of the agricultural sectors in Indonesia that survives and incurs profit during the Covid19 pandemic is oyster mushrooms (Pleurotus sp.) cultivation. Samarinda is one of the cities in Indonesia that produces oyster mushrooms. In 2019, Samarinda was the highest mushroom producer compared to the nine cities in East Kalimantan. Its production was up to $11,372 \mathrm{~kg}$, and the highest productivity level was $44,42 \mathrm{~kg} / \mathrm{m} 2$. The processes in cultivating oyster mushrooms are creating planting media, putting media in a plastic bag (the media in a plastic bag called baglog), sterilizing the baglogs; cooling the baglogs, carrying out inoculation process (planting a small number of fungus mycelia in the baglog), an opening ring of baglog, watering the kubung (the place to cultivate oyster mushroom), and harvesting the oyster mushroom. During the oyster mushroom cultivation process, farmers experience pain in several body segments, especially the waist. These were attributable to the working condition that requires non-ergonomic postures such as frequent awkward posture in sitting or standing position (such as in making planting media, sterilizing baglog, open baglog's ring, and harvesting processes) and repetitive handwork (such as inputting media into the plastic bag and open baglog's ring processes). Based on these problems, it is necessary to assess the working posture of oyster mushroom farmers, especially in Samarinda, to understand the potential risks of their working posture. Working with an ergonomic posture leads to minimal injuries.

Ovako Working Posture Analysis System (OWAS) method was applied to evaluate the working posture of oyster mushroom farmers. The OWAS method aims to identify frequency and time spent in a given task posture, evaluate the situation, and recommend the corrective actions (Karhu et al., 1977 in Gomez-Galan et al., 2017). OWAS method was used to evaluate the working posture of oyster mushroom farmers in this paper because it has been applied to fields (i.e., manufacturing, health care and social, housework activities, mining, agriculture, and forestry) (Gomez-Galan et al., 2017). Furthermore, as stated in Gomez-Galan et al. (2017), the OWAS method was applied in the agricultural field such as vineyard, farm (horticultural), nursery (eucalyptus), and plantation (palm, asparagus, and rubber). However, none of the studies was used the OWAS method in oyster mushroom cultivation.

\section{MATERIALS AND METHODS}

Data collection was conducted at four oyster mushroom cultivations located in Lempake, Samarinda, Indonesia. The respondents were owners and workers of the oyster mushroom cultivation aged between 20-38 years old and had at least four years of experience. The observation and documentation method was used to collect data on farmer's working postures. There were ten activities observed in this study. The photographs of the farmer's working postures in each activity were assessed and analyzed manually using the OWAS worksheet.

OWAS method is a method used to assess working posture at work. OWAS method is a simple method and can be used to analyze the load on working postures (Karhu et al., 1981). OWAS method was used to improve workers' conditions at work so that work performance can be improved continuously. This method provides output in the form of a risky working posture category for work accidents in the musculoskeletal section. OWAS method encodes work posture at the back, arms, feet, and weight of the load. Each section has its classification. Therefore, this method quickly identifies work posture that can cause work accidents in the human musculoskeletal system. In addition, in the agricultural sector, the OWAS method has been more frequently used compared to other methods, as the most favorable to evaluate the postures of farmers and above all for its simple 
application (Vanderschilden, 1989). Therefore, the application of the OWAS method has been studied in the agricultural sector, such as in vineyards, horticultural crops, asparagus farmers, apple harvesting, charcoal industry, oil palm fruit pickers, and rubber agro-industry workers (Gómez-Galán et al., 2017).

The basic OWAS posture is compiled with a code consisting of four digits, arranged sequentially starting from the back, arms, legs, and the weight load of manual material handling (Karhu et al., 1981). The following is a classification of the posture of the observed body parts for analysis and evaluation.

a. Position of back: straight (score: 1), bent forward or backward (score: 2), twisted or bent sideways (score: 3), bent or twisted forward or backward (score: 4)
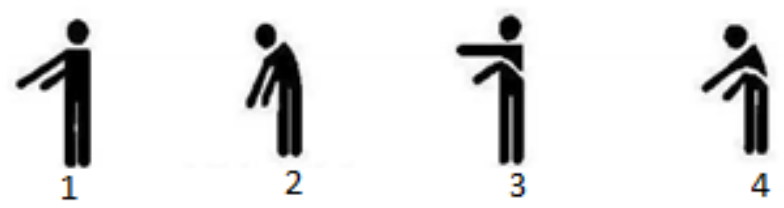

Figure 1. Classification of back working posture

b. Position of arms: both arms are below shoulder level (score: 1), one arm is at or above shoulder level (score: 2), both arms are at or above shoulder level (score: 3 )
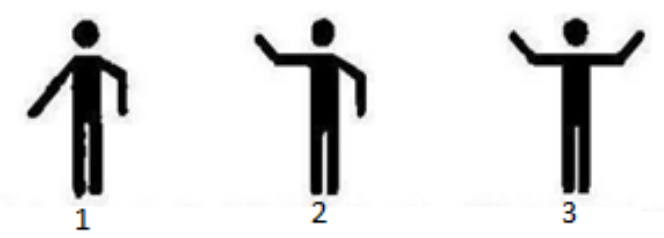

Figure 2. Classification of arm working posture

c. Position of legs: sitting (score: 1), standing with both legs straight (score: 2), standing with weight on one straight leg (score : 3), standing or squatting with both bent knees (score: 4), standing or squatting with one bent knee (score: 5), kneeling on one knee or both knees (score: 6), walking or moving (score: 7)

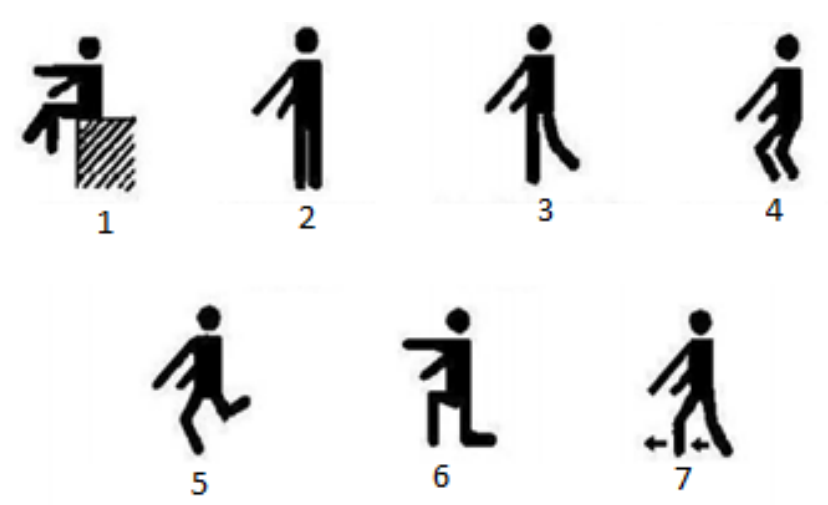

Figure 3. Classification of leg working posture

Table 1. OWAS action category

\begin{tabular}{|c|c|c|c|c|c|c|c|c|c|c|c|c|c|c|c|c|c|c|c|c|c|c|c|}
\hline \multirow{2}{*}{ Back } & \multirow{2}{*}{ Arms } & \multicolumn{4}{|c|}{1} & \multicolumn{2}{|l|}{2} & \multicolumn{3}{|c|}{3} & \multicolumn{3}{|c|}{4} & \multicolumn{3}{|c|}{5} & \multicolumn{3}{|c|}{6} & \multicolumn{3}{|c|}{7} & \multirow{2}{*}{$\begin{array}{l}\text { Legs } \\
\text { Load }\end{array}$} \\
\hline & & 1 & 2 & 3 & 1 & 2 & 3 & 1 & 2 & 3 & 1 & 2 & 3 & 1 & 2 & 3 & 1 & 2 & 3 & 1 & 2 & 3 & \\
\hline \multirow[t]{3}{*}{1} & 1 & 1 & 1 & 1 & 1 & 1 & 1 & 1 & 1 & 1 & 2 & 2 & 2 & 2 & 2 & 2 & 1 & 1 & 1 & 1 & 1 & 1 & \\
\hline & 2 & 1 & 1 & 1 & 1 & 1 & 1 & 1 & 1 & 1 & 2 & 2 & 2 & 2 & 2 & 2 & 1 & 1 & 1 & 1 & 1 & 1 & \\
\hline & 3 & 1 & 1 & 1 & 1 & 1 & 1 & 1 & 1 & 1 & 2 & 2 & 3 & 2 & 2 & 3 & 1 & 1 & 1 & 1 & 1 & 2 & \\
\hline \multirow[t]{3}{*}{2} & 1 & 2 & 2 & 3 & 2 & 2 & 3 & 2 & 2 & 3 & 3 & 3 & 3 & 3 & 3 & 3 & 2 & 2 & 2 & 2 & 3 & 3 & \\
\hline & 2 & 2 & 2 & 3 & 2 & 2 & 3 & 2 & 3 & 3 & 3 & 4 & 4 & 3 & 4 & 4 & 3 & 3 & 4 & 2 & 3 & 4 & \\
\hline & 3 & 3 & 3 & 4 & 2 & 2 & 3 & 3 & 3 & 3 & 3 & 4 & 4 & 4 & 4 & 4 & 4 & 4 & 4 & 2 & 3 & 4 & \\
\hline \multirow[t]{3}{*}{3} & 1 & 1 & 1 & 1 & 1 & 1 & 1 & 1 & 1 & 2 & 3 & 3 & 3 & 4 & 4 & 4 & 1 & 1 & 1 & 1 & 1 & 1 & \\
\hline & 2 & 2 & 2 & 3 & 1 & 1 & 1 & 1 & 1 & 2 & 4 & 4 & 4 & 4 & 4 & 4 & 3 & 3 & 3 & 1 & 1 & 1 & \\
\hline & 3 & 2 & 2 & 3 & 1 & 1 & 1 & 2 & 3 & 3 & 4 & 4 & 4 & 4 & 4 & 4 & 4 & 4 & 4 & 1 & 1 & 1 & \\
\hline \multirow[t]{3}{*}{4} & 1 & 2 & 3 & 3 & 2 & 2 & 3 & 2 & 2 & 3 & 4 & 4 & 4 & 4 & 4 & 4 & 4 & 4 & 4 & 2 & 3 & 4 & \\
\hline & 2 & 3 & 3 & 4 & 2 & 3 & 4 & 3 & 3 & 4 & 4 & 4 & 4 & 4 & 4 & 4 & 4 & 4 & 4 & 2 & 3 & 4 & \\
\hline & 3 & 4 & 4 & 4 & 2 & 3 & 4 & 3 & 3 & 4 & 4 & 4 & 4 & 4 & 4 & 4 & 4 & 4 & 4 & 2 & 3 & 4 & \\
\hline
\end{tabular}

d. Load/effort or weight handle: weight or effort or force is $10 \mathrm{~kg}$ or less $(\mathrm{W} \leq 10 \mathrm{Kg}$ ) (Score : 1 ), weight or effort or force is $10 \mathrm{Kg}-20 \mathrm{Kg}(10$
$\mathrm{Kg}<\mathrm{W} \leq 20 \mathrm{Kg}$ ) (score : 2), weight or effort or force is more than $20 \mathrm{Kg}(\mathrm{W}>20 \mathrm{Kg})$ (Score : 3 ). 
After the score for each body segment in each activity was determined, the risk level is categorized based on the OWAS worksheet in Table 1. The OWAS method of working posture analysis results consists of four working posture scale levels that are harmful to workers. The following are four levels of the employee posture scale based on the OWAS method: $1^{\text {st }}$ category: in this posture, there is no problem with the musculoskeletal system. Therefore, there is no need for improvement; $2^{\text {nd }}$ category: this posture is harmful to the musculoskeletal system, working posture causes a significant tension effect. Need improvement in the future; $3^{\text {rd }}$ category: this posture is dangerous to the musculoskeletal system, working posture results in a very significant effect of tension. Need improvement as soon as possible. $4^{\text {th }}$ category: this posture is very dangerous for the musculoskeletal system. This working posture results in a substantial risk. Need immediate or immediate improvement.

\section{RESULTS AND DISCUSSIONS}

The oyster mushroom cultivation process in Lempake, Samarinda consists of several steps. The first step is the process of making planting media in the form of mixing sawdust with bran, lime and gypsum according to the dose to get an exact media composition. The rating result with the OWAS method is shown in Table 2. The rating result using the OWAS method has a "4141" score. Based on the OWAS category, the " 4141 " score was categorized as the $4^{\text {th }}$ category, which means this posture is dangerous and causing a risk that needs immediate improvement.

After the sawdust mixture is tightly closed using plastic and left for one night, the next step is to put it in a plastic bag (baglog) with a specific density so that the mushroom mycelia can grow optimally produce optimal harvests - the rating result with the OWAS method as shown in Table 3. The rating result using the OWAS method has a "4111" score. Based on the OWAS category, the " 4111 " score is categorizing as the $2^{\text {nd }}$ category, which means this posture is dangerous and needs improvement in the future.

The next step is the sterilization process. Sterilization is a process carried out to inactivate microbes, bacteria, molds, and yeasts that can interfere with the growth of planted fungi. The goal is to get sterile sawdust free from microbes and other unwanted fungi. The rating result with the OWAS method is showing in this table 4. The rating result using the OWAS method has a "4121" score. Based on the OWAS category, the score "4121" is including in category $2^{\text {nd }}$, which means this posture is dangerous and needs improvement in the future.

Then, the cooling process is carried out. The cooling process is an effort to reduce the temperature of the growing media after sterilization to avoid dead seeds in the baglog. The rating result of using the OWAS method is shown in Table 5. The rating result with the OWAS method has a "4121" score. Based on the OWAS category, the " 4121 " score is categorized as the $2^{\text {nd }}$ category, which means this posture is dangerous and needs improvement in the future.

The next stage is seed inoculation. Inoculation is the process of transferring a small number of fungal mycelia from the parent culture into the plant media that has been provided. The goal is to grow mushroom mycelia on the planting medium to produce mushrooms ready to harvest. Rating results with the OWAS method can be seen in Table 6 . The rating result with the OWAS method has a "4111" score. Based on the OWAS category, the " 4111 " score is categorized as the $2^{\text {nd }}$ category, which means this posture is dangerous and needs improvement in the future.

When the inoculation process was completed, the incubation step is started. Incubation is storing or placing the inoculated planting media in certain room conditions so that fungal mycelia grow. The goal is to get mycelial growth. The white baglog overgrown with mycelium was then transferred to the cultivation medium (kumbung). Baglog in which mycelium is white and thickening, the bamboo ring is opened to grow the fungus. The rating result of using the OWAS method is shown in Table 7. The rating result with the OWAS method has a "2111" score. Based on the OWAS category, the "2111" score is categorized as the $2^{\text {nd }}$ category, which means this posture is dangerous and needs improvement in the future.

Baglogs that have been ring-opened are treated by watering to accelerate the growth of fungal pinheads. The rating result with the OWAS method can be seen in the Table 8 . The rating result with the OWAS method has a "4121" score. Based on the OWAS category, the " 4121 " score is categorized as the $2^{\text {nd }}$ category, which means this posture is dangerous and needs improvement in the future.

The last step is the harvesting process. The harvested mushrooms are cleaned and then packed into plastic bags of $3 \mathrm{~kg}, 5 \mathrm{~kg}, 10 \mathrm{~kg}$ and ready to be marketed. Rating result using OWAS method is shown in this Table 9, Table 10, and Table 11. 
Table 2. Calculation of the OWAS score in the mixing of raw materials

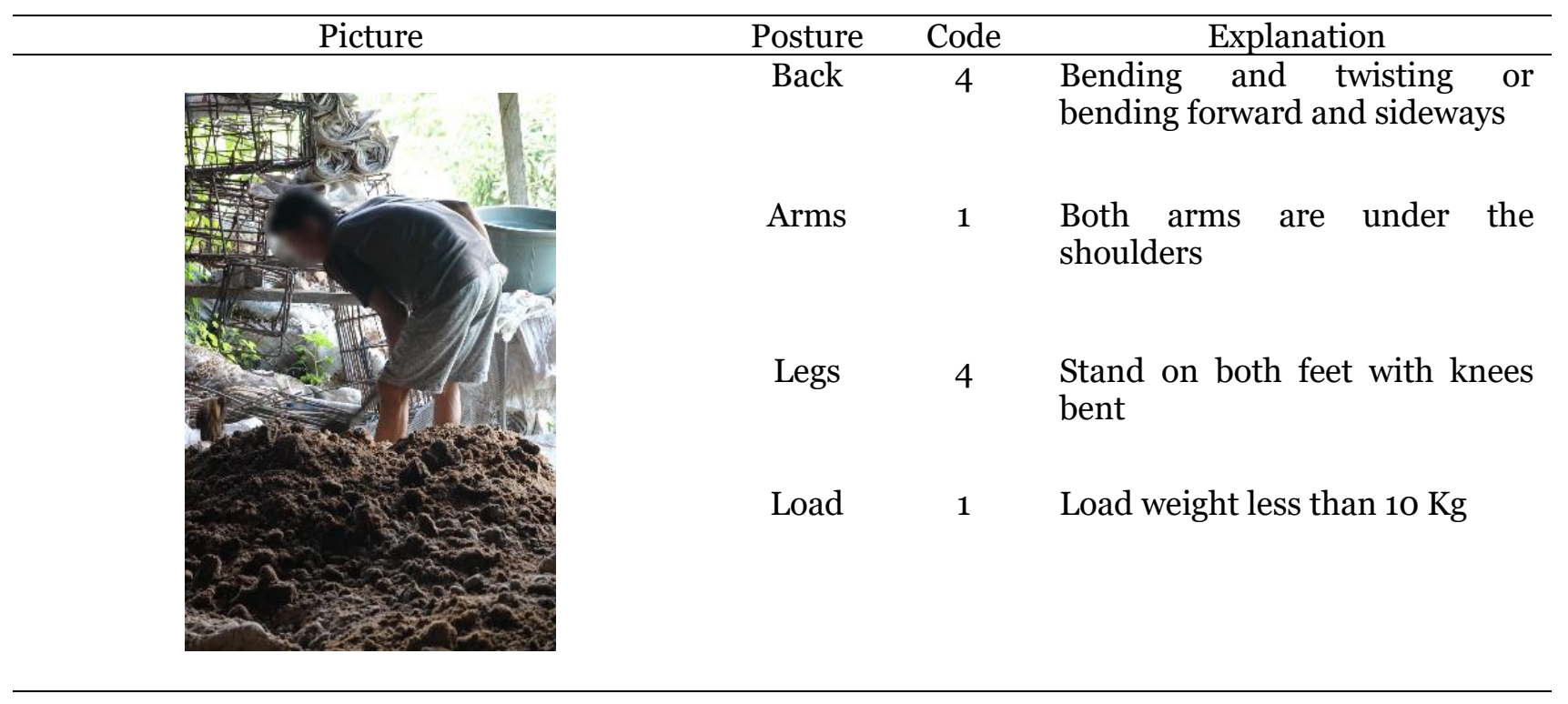

Table 3. Calculation of OWAS score in the activity of inserting media into baglog

\begin{tabular}{cccl} 
Posture & Code & \multicolumn{1}{c}{ Explanation } \\
\hline Bicture & 4 & $\begin{array}{l}\text { Bending and twisting or bending } \\
\text { forward and sideways }\end{array}$ \\
Legs & 1 & $\begin{array}{l}\text { Both arms are under the } \\
\text { shoulders }\end{array}$ & Sit chair $20 \mathrm{~cm}$ \\
Load weight less than $10 \mathrm{Kg}$
\end{tabular}

Table 4. Calculation of OWAS score in sterilization

\begin{tabular}{cccl}
\hline Picture & Posture & Code & \multicolumn{1}{c}{ Explanation } \\
\hline Back & 4 & $\begin{array}{l}\text { Bending and twisting or bending } \\
\text { forward and sideways }\end{array}$ \\
Arms & 1 & $\begin{array}{l}\text { Both arms are under the } \\
\text { shoulders }\end{array}$ & Stand on both straight legs \\
Legs & 2 & 1 & Woad
\end{tabular}


Table 5. Calculation of OWAS score in the cooling process

\begin{tabular}{llll}
\hline Picture & Posture & Code & \multicolumn{1}{c}{ Explanation } \\
\hline Back & 4 & $\begin{array}{l}\text { Bending and twisting or bending } \\
\text { forward and sideways }\end{array}$ \\
Arms & 1 & $\begin{array}{l}\text { Both arms are under the } \\
\text { shoulders }\end{array}$ & Stand on both straight legs \\
Legs & 2 & 1 & Weight load was less than $10 \mathrm{~kg}$
\end{tabular}

Table 6. Calculation of OWAS score in inoculation process

\begin{tabular}{lccl}
\hline Picture & Posture & Code & \multicolumn{1}{c}{ Explanation } \\
\hline Back & 4 & $\begin{array}{l}\text { Bending and twisting or bending } \\
\text { forward and sideways }\end{array}$ \\
Arms & 1 both arms are under the \\
shoulders & Cross-leg sit \\
Legs & 1 & Weight load was less than $10 \mathrm{~kg}$
\end{tabular}

Table 7. Calculation of OWAS score in the ring-opening process

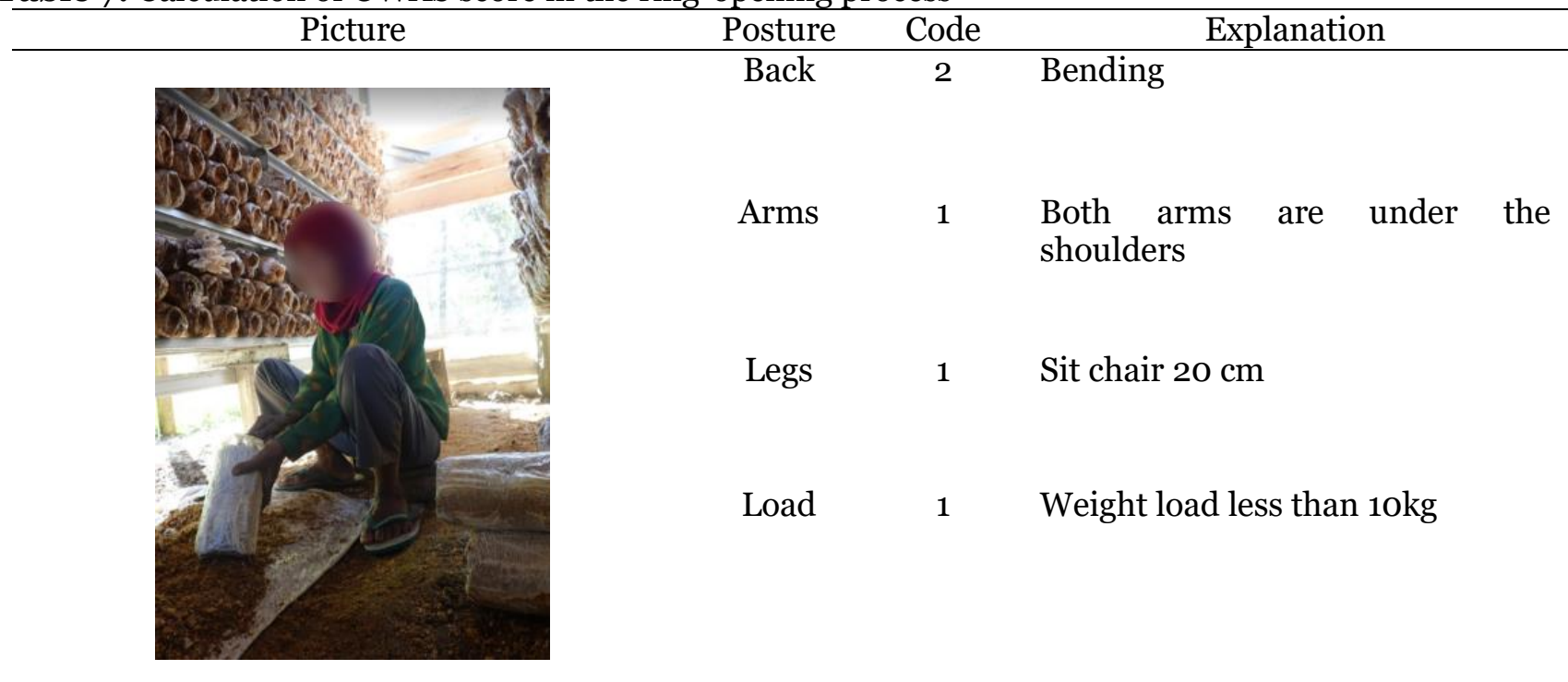


Table 8. Calculation of OWAS score in the watering process

\begin{tabular}{cccc}
\hline Picture & Posture & Code & \multicolumn{1}{c}{ Explanation } \\
\hline Back & 4 & $\begin{array}{c}\text { Bending and twisting or bending } \\
\text { forward and sideways }\end{array}$ \\
Legs & Arms & 1 & $\begin{array}{l}\text { Both arms are under the } \\
\text { shoulders }\end{array}$ \\
Stand on two straight legs
\end{tabular}

Table 9. Calculation of OWAS score in the upper shelf harvesting process

\begin{tabular}{lccc}
\hline & Posture & Code & Explanation \\
\hline & Back & 1 & Straight \\
& Legs & 2 & $\begin{array}{l}\text { One arm is under the shoulder; } \\
\text { the other is above the shoulder }\end{array}$ \\
Stand on two straight legs
\end{tabular}

Table 10. OWAS score calculation in harvesting process at the middle shelf

\begin{tabular}{cccc} 
Picture & Posture & Code & Explanation \\
\hline Back & 1 & Straight & \\
Lrms & 2 & One arm is above the shoulders \\
Legs & 2 & Stand on two straight legs \\
Load & 1 & Weight load is less than $10 \mathrm{~kg}$
\end{tabular}


Table 11. OWAS score calculation in the harvesting of the bottom shelf

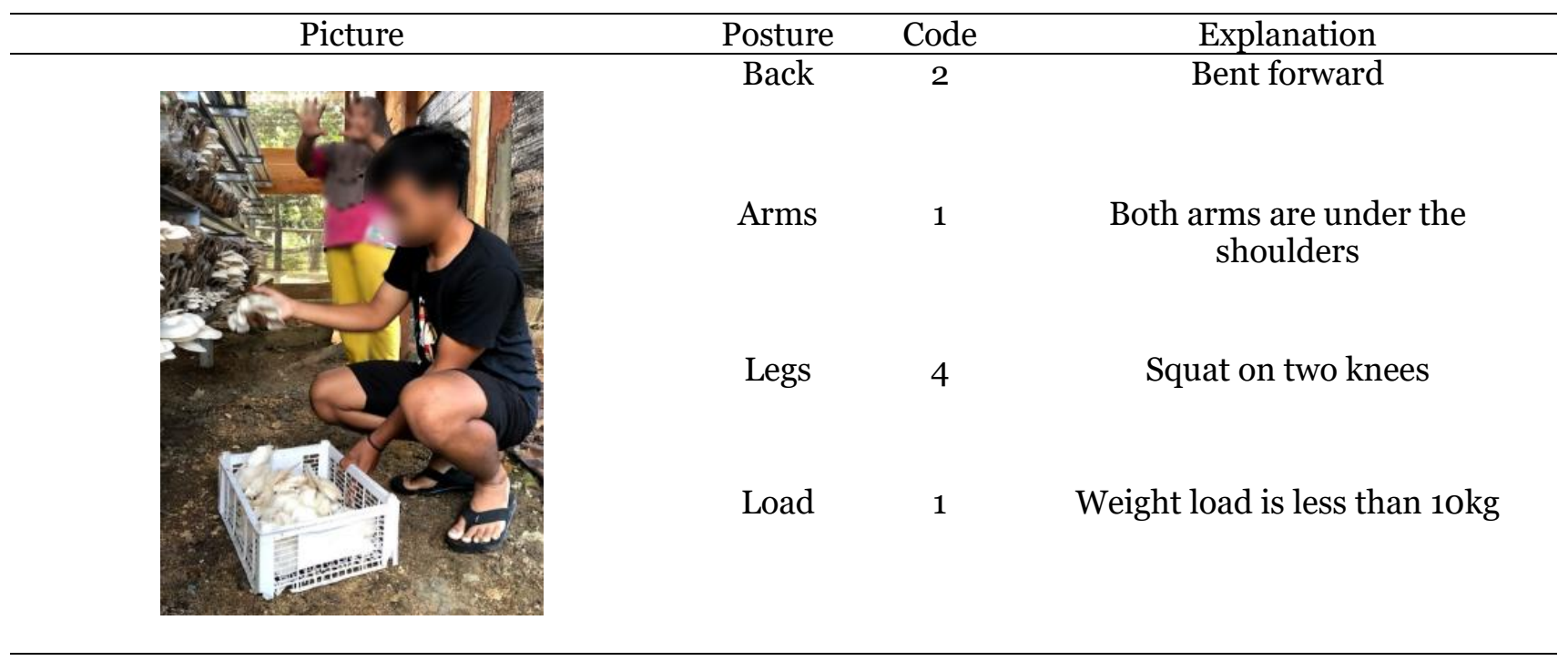

The rating result using the OWAS method for upper shelf harvesting process and harvesting process at middle shelf have a "1221" score. The OWAS category's "1221" score is the $1^{\text {st }}$ category, which means this posture is safe and needs no improvement. The rating result with the OWAS method has a "2141" score. Based on the OWAS category, the "2141" score is categorized as the $3^{\text {rd }}$ category, which means this posture is dangerous and needs improvement as soon as possible.

Based on the results of calculations using the OWAS method, which are summarized in
Table 12, it was found that the majority of the work postures of oyster mushroom farmers were in the $2^{\text {nd }}$ category, which is a moderate level of risk for the musculoskeletal system. There are six activities in this category or about $60 \%$ of the total oyster mushroom cultivation activity. Meanwhile, very dangerous postures are only $10 \%$ of the total activity, and $20 \%$ are included in a safe work posture or low-risk level. The remaining $10 \%$ is included in a dangerous working posture.

Table 12. Recapitulation of OWAS score on oyster mushroom cultivation activities

\begin{tabular}{lccc}
\hline \multicolumn{1}{c}{ Activity } & OWAS Score & OWAS Category & Risk Level \\
\hline Mixing of raw materials & 4141 & 4 & Very High \\
Inserting media into baglog & 4111 & 2 & Medium \\
Sterilization & 4121 & 2 & Medium \\
Cooling process & 4121 & 2 & Medium \\
Inoculation process & 4111 & 2 & Medium \\
Ring-opening process & 2111 & 2 & Medium \\
Watering process & 4121 & 2 & Medium \\
The upper shelf harvesting process & 1221 & 1 & Low \\
Harvesting process at the middle shelf & 1221 & 1 & Low \\
Harvesting of the bottom shelf & 2141 & 3 & High \\
\hline
\end{tabular}

Table 13 shows that the working posture with a back turning to the left or right is the most frequently performed by oyster mushroom farmers, $60 \%$. In addition, $20 \%$ of farmers carry out activities with bending back. At the same time, $20 \%$ of activities were performed with a neutral position of the back. In terms of arm posture, $80 \%$ of farmers performed activities with their hands under their shoulders. It is relatively safe because it is the lowest OWAS score for the arm posture. As for the position of the legs, $50 \%$ of the farmers stand with their straight legs, $30 \%$ of the farmers are in a sitting position, and the rest $20 \%$ are in a standing or squatting position with both bent knees.

Non-ergonomic sitting or standing postures such as bending, leaning the body and head forward, lifting and carrying heavy loads, and repetitive handwork is often carried out in the agricultural sector (Jain, 2018, Dianat et al., 2020, Choi et al., 2020). Research conducted by Utami et al. (2017) shows that the working posture of farmers was categorized as bad because the work is performed manually in an awkward position. These are confirmed in this study. The position of non-ergonomic postures is 
found in task mixing of raw materials, inserting media to baglog, sterilization process, cooling process, inoculation process, ring-opening process watering process, and harvesting in bottom shelves. These activities are included in non-ergonomic posture because the back is bending or twisting or the legs are in a squatting position. The risk level of these postures is in the medium to very high category. The back position bent and twisted/sideways is the most high-risk position for MSDs (Donham and Thelin, 2015; Priyambada and Suharyanto, 2019). Another study found that the back sideways/twisted position and bent over in a standing position with one leg bent/holding were the highest risk of MSDs (Tella et al., 2013).

Table 13. Recapitulation of working posture based on OWAS

\begin{tabular}{clc}
\hline Body Segment & \multicolumn{1}{c}{ Posture } & Percentage \\
\hline \multirow{3}{*}{ Back } & Straight & 20 \\
& Bent forward or backward & 20 \\
& Twisted or bent sideways & 0 \\
& Bent or twisted forward or backward & 60 \\
& Both arms are below shoulder level & 80 \\
& One arm is at or above shoulder level & 20 \\
& Both arms are at or above shoulder level & 0 \\
& Sitting & 30 \\
& Standing with both legs straight & 50 \\
& Standing with weight on one straight leg & 0 \\
& Standing or squatting with both bent knees & 20 \\
& Standing or squatting with one bent knee & 0 \\
& Kneeling on one knee or both knees & 0 \\
& Walking or moving & 0 \\
& Weight or effort or force is 10 kg or less $(\mathrm{W} \leq 10 \mathrm{Kg})$ & 100 \\
& Weight or effort or force is 10 Kg - 20 Kg $(10 \mathrm{Kg}<\mathrm{W} \leq 20 \mathrm{Kg})$ & 0 \\
& Weight or effort or force is more than $20 \mathrm{Kg}(\mathrm{W}>20 \mathrm{Kg})$ & 0 \\
\hline
\end{tabular}

Humantech (1995) explained that one of the factors of injuries to the musculoskeletal system is awkward posture. Unnatural working postures or awkward working postures are working postures that are carried out with the body position moving away from natural positions such as a back that is too bent, hands in a raised position, a squatting position, a twisted body position, and others. This unnatural working posture is generally due to the characteristics of activity, work tools, and work stations, which do not match the abilities and limitations of workers (Grandjean, 1993; Anis \& McConville, 1996; Waters \& Anderson, 1996 \& Manuaba, 2000 in Tarwaka (2010)).

In mixing raw materials, one of the factors that cause the risk level score to be in the very high category is a bending and twisting postures when hoeing the material using a manual hoe. Moreover, both legs are not straight and bend for quite a long time. Improvement that can be made to reduce the level of risk is replacing manual tools with more modern tools so that farmers do not have to bend over while working. Similar to the activities of inserting media into baglog, ringopening process, and seed inoculation process, farmers have to carry out these activities with their backs bent because they have to reach the material, but this work is done by sitting in a chair so that the level of risk is medium. As for the sterilization, cooling process, and watering process activities, they are included in the medium category because these activities require the back not only bending but also twisting to the right or left, but these activities carry out with straight legs so that these activities are included in the medium risk level category. Meanwhile, harvesting of bottom shelf activity is included in the high category because apart from a bent back, the legs are also in a squatting position. It is because the location of the mushroom is at the bottom of the shelf, so farmers have to squat down to pick up the mushrooms. It also can be improved by redesigning the shelf so farmers do not have to squat down when they reach the bottom of the mushroom cultivation shelf.

\section{REFERENCES}

Ardiansyah, R., (2018). Analisis tingkat resiko ergonomi pada petani karet di Kelurahan Cambai, Kecamatan Cambai Kota Prabumulih [Skripsi. Universitas Sriwijaya]

Choi, K. H., Kim, D. M., Cho, M. U., Park, C. W., Kim, S. Y., Kim, M. J., and Kong, Y. K. (2020). Application of AULA risk assessment tool by comparison with other ergonomics risk assessment tools. International Journal of Environment 
Research and Public Health, 17(8). https://10.3390/ijerph17186479.

Das, B.. (2015). Gender differences in prevalence of musculoskeletal disorders among the rice farmers of West Bengal, India. Work, 5O(2), 229-240. https://10.3233/WOR131694.

Dianat, I., Afshari, D., Sarmasti, N., Sangdeh, M. S., and Azaddel, R. (2020). Work posture, working conditions, musculoskeletal outcomes in agricultural worker. International Journal of Industrial Ergonomics, https://10.1016/j.ergon.2020.102941.

Donham, K.J., and Thelin, A. (2015). Agricultural medicine - rural occupational and environmental health, safety, and prevention. John Wiley \& Sons. https://10.1002/9781118647356.

Fathallah, F.A. (2010). Musculoskeletal disorders in labor-intensive agriculture. Appl. Ergon. 41(6),738-743.

https://doi.org/10.1016/j.apergo.2010.03. o03.

Gómez-Galán, M., Pérez-Alonso, J., CallejónFerre, Á.J., López-Martínez. (2017). Musculoskeletal disorders: OWAS review. Industrial Health, 55(4). https://10.2486/indhealth.2016-0191.

Grandjean, E. (1993). Fitting the task to the man: a textbook of occupational ergonomics, 4th ed., Taylor and Francis Inc., London.

Hildebrandt, V.H. (1995). Musculoskeletal symptoms and workload in 12 branches of Dutch agriculture. Ergonomics, 38(12), 2576-2587.

https://doi.org/10.1080/00140139508925 287.

Humantech. (1995). Applied ergonomics training manual $2^{\text {nd }}$. Australia, Barkeley Vale.

ILO. (2020). Safety and Health in Agriculture. International Labour Office, Switzerland.

Jain, R., Meena, M. L., Dangayach, G. S., and Bhardwaj, A. K. (2018). Risk factors for musculoskeletal disorders in manual harvesting farmers of Rajasthan. Industrial Health, 56(3), pp. 241-248, https://10.2486/indhealth.2016-0084

Kang, M.Y., Lee, M.J., Chung, H., Shin, D.H., Youn, K.W., Im, S.H., Chae, H.S., Lee, K.S. (2016) Musculoskeletal disorders and agricultural risk factors among Korean farmers. J. Agromed, 21(4), 353-363. https://doi.org/10.1080/1059924X.2016.1 178612.

Karhu, O., Härkönen, R., Sorvali P., and Vepsäläinen P. (1981). Observing working postures in industry: examples of OWAS application. Applied Ergonomics, 12(1), 1317. https://10.1016/0003-6870(81)900880.

Lee, S.J., Tak, S., Alterman, T., Calvert, G.M. (2014). Prevalence of musculoskeletal symptoms among agricultural workers in the United States: an analysis of the National Health Interview Survey 20042008. J. Agromed, 19(3), 268-280. https://doi.org/10.1080/1059924X.2014.9 16642.

López-Aragón, L., López-Liria, R., Callejón-Ferre, A.J., Pérez-Alonso, J. (2018). Musculoskeletal disorders of agricultural workers in the greenhouses of Almería (Southeast Spain). Safety Science, 109, 219-235. https://doi.org/10.1016/j.ssci.2018.05.023

McCurdy, S.A., Samuels, S.J., Carroll, D.J., Beaumont, J.J., Morrin, L.A. (2003). Agricultural injury in California migrant Hispanic farm workers. Am. J. Ind. Med., 44(3), $\quad 225 \quad-\quad 235$. https://doi.org/10.1002/ajim.10272.

Min, D., Baek, S., Park, H.W., Lee, S.A., Moon, J., Yang, J.E., Kim, K.S., Kim, J.Y., Kang, E.K. (2016). Prevalence and characteristics of musculoskeletal pain in Korean Farmers. Ann.Rehab. Med., 4O(1), 1-13. https://doi.org/10.5535/arm.2016.40.1.1.

Naidoo, S., Kromhput, H., London, L., Naidoo, R.N., Burdorf, A. (2009). Musculoskeletal pain in women working in small-scale agriculture in South Africa. Am. J. Ind. Med., $\quad$ 52(3), 202-209. https://doi.org/10.1002/ajim.20662.

Niu, S. (2010). Ergonomics and occupational safety and health: an ILO perspective. Appl. Ergon., 41(6), 744-753. https://doi.org/10.1016/j.apergo.2010.03. 004.

Nurmianto, E. (2004). Ergonomi: konsep dasar dan aplikasinya. Guna Widya.

Osborne, A., Blake, C., McNamara, J., Meredith, D., Phelan, J., Cunningham, C. (2010). Musculoskeletal disorders among Irish farmers. Occup. Med., 6o(8), 598-603. https://doi.org/10.1093/occmed/kqq146.

Pratiwi, A.P. (2020). Analisis faktor yang berpengaruh terhadap keluhan musculoskeletal pada pekerja petani rumput laut wanita di Kabupaten Takalar [Tesis. Universitas Hasanudin]

Priyambada, G., and Suharyanto, S. (2019). Analisis risiko postur kerja di industri kelapa sawit menggunakan metode ovako working analysis system dan nordic body map pada stasiun pemanenan dan 
penyortiran tbs. Jurnal Teknik Lingkungan, 24(2). https://doi.org/10.5614/j.tl.2019.25.1.4.

Tarwaka, Sholichul, and Sudiajeng, L. (2004). Ergonomi untuk keselamatan, kesehatan kerja dan produktivitas. UNIBA PRESS.

Tarwaka. (2010). Ergonomi industri dasardasar pengetahuan ergonomi dan aplikasi di tempat kerja. Harapan Press.

Tella, B.A., Akinbo, S.R.A., Asafa, S.A., and Gbiri, C.A. (2013). Prevalence and impacts of low back pain among peasant farmers in South-West Nigeria. Int $J$ Occup Med Environ Health, 26. https://doi.org/10.2478/s13382-013-0135$\mathrm{x}$.
Utami, U., Kamrimuna, S.R., and Jufri, N. (2017). Hubungan lama kerja, sikap kerja dan beban kerja dengan musculoskeletal disorders (MSDs) pada petani padi di desa ahuhu Kecamatan Meluhu Kabupaten Konawe tahun 2017. Jurnal Ilmiah Mahasiswa Kesehatan Masyarakat, 2(6). https://10.37887/jimkesmas.v2i6.2921.

Vanderschilden, M. (1989). The OWAS system for analysing working postures. 11th Workshop On Labour and Labour Management, Wageningen, Netherlands. 129-36. 